\title{
Lo que puede esconder una ciatalgia
}

\section{What a ciatalgia can hide}

Varón de 60 años sin antecedentes de interés, que acude a urgencias en repetidas ocasiones por ciatalgia unilateral de 3 meses de evolución, que no cede a pesar de tratamiento convencional. Por dicho motivo se solicita TC de pelvis donde se evidencian una masa ligada al nervio ciático (imagen 1 y 2). En el estudio de extensión se solicita TC torácico y abdominal, donde se evidencian lesiones ocupantes de espacio en hígado y pulmón, lesiones osteoclásticas y múltiples adenopatías retroperitoneales y mediastínicas. Antes estos hallazgos se realizó una biopsia de la masa glútea, obteniendo el siguiente estudio anatomopatológico: áreas densamente celulares y áreas de matriz hialina, núcleos fusiformes y ovoides con citoplasmas eosinófilos, se tiñe con \$100, enolasa neuronal y CD 57; es negativo para citoqueratinas, melanocitos, linfocitos y estirpe epitelial; todo esto compatible con tumor maligno de vaina de nervio periférico (Nervio ciático). El paciente presentaba dolor incontrolado por lo que se inició radioterapia antiálgica sobre la lesión y posteriormente tratamento quimioterápico, con mala evolución siendo éxitus.

El tumor maligno de vaina de nervio periférico es raro, solo representa un 5-10\% de los sarcomas de tejidos blandos. Se puede asociar a neurofibromatosis pero hasta el $50 \%$ son esporádicos. El rango de edad suele ser de los 5 a 75 años, siendo la $5^{\circ}$ y $6^{\circ}$ década las de mayor prevalencia. El género más afectado suele ser el masculino. La clínica predominante la local (tumefacción) y la irritación del nervio (dolor neuropático). El diagnóstico se establece a través del estudio anatomopatológico, en el que se observa tinción frente a $\$ 100$ y p53. El tratamiento suele ser cirugía radical y radioterapia, pero el pronóstico es infausto hasta para los que se extirpan con intención curativa.

\section{Bibliografía}

1. Stark AM, Buhl R, Hugo HH, Mehdorn HM. Malignant peripheral nerve sheath tumours-report of 8 cases and review of the literature. Acta Neurochir (Wien), 2001; 143(4):357-63.

2. Ziadi A, Saliba L. Maliggnant peripheral nerve shealth tumor of intracranial nerve: a case series review. Auris Nasus Larynx. 2010 0CT; 37 (5):539-45.
Imágenes 1 y 2 . Masa ligada al nervio ciático.
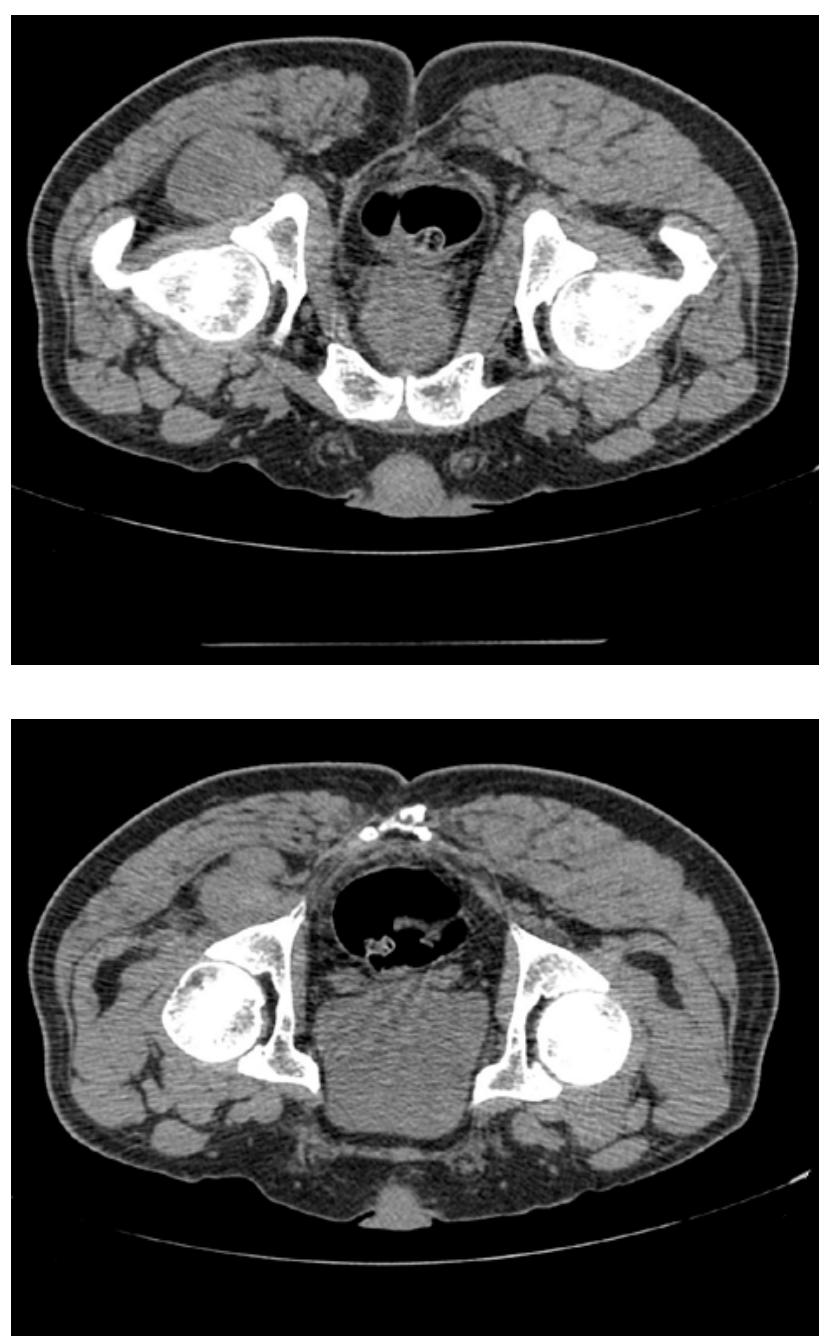

Diagnóstico

\section{Tumor maligno de vaina de nervio periférico (Nervio ciático)}

Cristina Sardiña-González. Manuel L. Lopez-Reboiro Servicio de Medicina Interna. Hospital Comarcal de Monforte

Correspondencia: manuel.Iorenzo.lopez.reboiro@sergas.es

Cómo citar este artículo: Sardiña-González C, Lopez-Reboiro ML

Lo que puede esconder una ciatalgia. Galicia Clin 2019; 80 (3): 63

Recibido: 09/09/2018; Aceptado: 29/10/2018 // http://doi.org/10.22546/53/1768 